\title{
PENAJAMAN PERAN PENGANGGARAN SEKTOR PUBLIK SEBAGAI ALAT PERENCANAAN DAN PENGENDALIAN
}

\author{
Ali Tafriji Biswan*, Defian Panji Ponco Kusumo \\ Politeknik Keuangan Negara STAN, Tangerang Selatan, Indonesia \\ Direktorat Jenderal Perbendaharaan Kementerian Keuangan Republik Indonesia \\ altafz2009@gmail.com,defianpanjiponcokusumo@gmail.com \\ https://doi.org/10.46367/jas.v5i1.341 \\ Received: May 02, 2021 Revised: Jun 05, 2021 Accepted: Jun 17, 2021 Published: Jun 28, 2021
}

\begin{abstract}
This study aims to examine the non-tax state revenue (NTSR) budgeting process at the Pesi Resort Police (object name be camouflaged). This study is a qualitative one with a comparative approach comparing the Resort Police's Budget Realization Report with the budgeting regulations. To meet the research objectives, conducted and processed data through literature studies and interviews. The study results found that most of the 96 percent NTSR came from services to the community in accordance with the duties and functions of the Resort Police. In general, the research object has fulfilled the budgeting process. However, it has not been carried out more carefully in terms of planning for NTSR revenue budget items. The realization of the NTSR target reaches 2,000 percent, considering that many revenue accounts are not budgeted. The study suggests that the study object should make a more detailed budget planning for each NTSR revenue budget item so that each item is more realistic so that it supports the use of NTSR funds to improve services according to budget as a planning controlling tool.
\end{abstract}

Keywords: Public Sector, Budgeting, Planning, Controlling.

\begin{abstract}
ABSTRAK
Penelitian ini bertujuan untuk menelaah proses penganggaran Penerimaan Negara Bukan Pajak (PNBP) di Kepolisian Resor (Polres) Pesi (nama objek disamarkan). Studi ini merupakan kualitatif dengan pendekatan komparatif ini membandingkan informasi Laporan Realisasi Anggaran (LRA) Polres dengan peraturan penganggaran. Untuk memenuhi tujuan penelitian, dilakukan pengumpulan dan pengolahan data melalui studi literatur, pengamatan, dan wawancara. Hasil penelitian menemukan bahwa sebagian besar yakni 96 persen PNBP berasal dari pelayanan kepada masyarakat sesuai dengan tugas dan fungsi Polres. Secara umum objek penelitian telah memenuhi proses penganggaran. Namun dalam hal perencanaan Mata Anggaran Penerimaan PNBP, belum dilakukan secara lebih cermat sehingga realisasi target PNBP mencapai 2.000 persen mengingat banyak akun pendapatan tidak dianggarkan. Studi menyarankan agar objek studi membuat perencanaan anggaran lebih rinci tiap Mata Anggaran Penerimaan PNBP sehingga capaian setiap item lebih realistis sehingga memungkinkan penggunaan dana PNBP untuk peningkatan layanan sesuai kegunaan anggaran sebagai alat perencanaan dan pengendalian.
\end{abstract}

Kata Kunci: Sektor Publik, Penganggaran, Perencanaan, Pengendalian. 


\section{PENDAHULUAN}

Sebagai salah satu skenario yang mendukung pembangunan segala bidang, penerimaan negara dari aspek bukan pajak penting diberdayakan selain dari aspek pajak. Undang-Undang Nomor 20 Tahun 1997 tentang Penerimaan Negara Bukan Pajak (PNBP) mengelompokan PNBP menjadi empat kelompok menurut filosofi pengelolaannya yaitu penerimaan fungsional, penerimaan umum, penerimaan badan layanan umum, dan penerimaan bendahara umum negara. Kelompok PNBP penerimaan fungsional merupakan pendapatan yang berasal dari aktivitas pelayanan pemenuhan kebutuhan dasar dan penunjang perekonomian oleh satuan kerja pemerintah kepada masyarakat berdasarkan tugas dan fungsinya (Presiden Republik Indonesia 1997). Polri sebagai bagian dari pemerintah yang bertugas untuk melayani dan mengayomi masyarakat termasuk kementerian atau lembaga (K/L) yang memiliki banyak jenis PNBP di antaranya pendapatan dari layanan penerbitan surat izin mengemudi (SIM), penerbitan surat tanda nomor kendaraan (STNK), dan pengamanan objek. Polri beserta jajaran di bawahnya tetap harus merencanakan PNBP dalam kerangka anggaran pendapatan dan belanja negara (APBN). Studi PNBP pada Polres Pesi (nama disamarkan) menunjukkan fakta unik dan menarik. Studi pendahuluan atas anggaran PNBP Polres Pesi menunjukkan bahwa realisasi PNBP hampir 2.000 persen.

Undang-undang nomor 20 tahun 1997 tentang penerimaan negara bukan pajak mendorong agar target PNBP disusun secara realistis dan optimal berdasarkan jenis dan tarif PNBP, akun pendapatan sesuai dengan bagan akun standar, serta perkiraan jumlah atau volume yang menjadi dasar penghitungan dari masing-masing jenis PNBP. Rencana target PNBP kemudian disusun dalam bentuk rencana target satuan kerja penghasil lalu direkapitulasi menjadi rencana target PNBP Polda. Di samping itu, rencana tersebut juga disusun dalam bentuk rencana target PNBP mabes Polri yang merupakan ajuan dari pembina fungsi pengelola PNBP. Dengan capaian realisasi anggaran PNBP mendapati hampir 2.000 persen mengimplikasikan permasalahan dalam perencanaan anggarannya.

Studi ini bertujuan mendalami peran penganggaran sebagai alat perencanaan dan pengendalian. Secara khusus studi mendalami mengapa realisasi menunjukkan capaian yang kurang wajar dan bagaimana usulan perbaikannya. Studi ini penting mengingat PNBP kelompok penerimaan fungsional di Polres cukup beragam dan terkait pelayanan kepada masyarakat, seperti SIM, STNK, dan pengamanan objek kegiatan. Objek studi di Polri khususnya Polres Pesi. Diambil objek kepolisian karena menarik dibahas bahwa kelompok penerimaan PNBP fungsional beragam, namun sedikit studi yang mengambil objek di lingkungan kepolisian padahal jenis PNBP kepolisian cukup beragam dan jumlahnya banyak.

Berangkat dari fenomena unik bahwa realisasi anggaran PNBP Polres Pesi hampir 2.000 persen. Studi awal menemukan bahwa capaian tersebut tidak diakibatkan oleh suatu peristiwa ketidakpastian dari faktor eksternal, dan sudah pernah terjadi periode sebelumnya. Dugaannya adalah angka realisasi sebelumnya belum dilakukan tindakan korektif. Keunikan penganggaran tersebut memicu peneliti mendalami lebih lanjut apa penyebab permasalahan, proses penganggaran PNBP apa yang sebenarnya terjadi, dan bagaimana usulan perbaikan penganggaran agar lebih baik periode mendatang. 


\section{TELAAH LITERATUR}

Komponen kunci perencanaan adalah anggaran yang merupakan rencana keuangan masa depan dari entitas yang mengidentifikasikan tujuan yang ingin dicapainya. Anggaran merupakan rencana yang buat secara tertulis oleh suatu organisasi dalam jangka waktu tertentu yang dinyatakan secara kuantitatif atau ditetapkan dengan angka-angka beserta kegiatan yang hendak dilaksanakan (Nafarin 2000). Anggaran ini umumnya dibuat dalam satuan moneter suatu negara atau bisa juga dinyatakan dengan satuan barang dan/atau jasa yang secara umum digunakan. Anggaran merupakan perencanaan keuangan organisasi yang digunakan sebagai dasar pengawasan keuangan untuk periode mendatang (Supriyono 1990). Terkait kegunaan, disebutkan bahwa anggaran memiliki beberapa manfaat, diantaranya anggaran memaksa manajer; untuk melakukan perencanaan dengan melihat peristiwa masa lampau secara menyeluruh; mengantisipasi masalah; serta menyusun kebijakan demi keberlangsungan hidup entitasnya (Hansen and Mowen 2007). Anggaran juga menyediakan informasi yang dapat digunakan untuk memperbaiki kualitas pengambilan keputusan dengan melihat peristiwa masa lampau sekaligus memprediksi kejadian masa depan. Anggaran dan pengendalian anggaran merupakan kunci perencanaan dan pengendalian pada sektor publik (Nwokeji 2009). Hal ini diperkuat bahwa anggaran publik merupakan alat manajemen penting untuk perencanaan dan pengendalian, ditunjukkan dengan ekspresi keuangan, menyangkut tujuan, biaya, aksi, yang didanai dari pendapatan, evaluasi hasil dan efisiensi ekonomi (Mihaela et al. 2010).

Pada sektor pemerintah, hal terkait penganggaran diatur melalui peraturan menteri keuangan selaku bendahara umum negara. Berdasarkan peraturan menteri keuangan (PMK) Nomor 208/PMK.02/2019 tentang petunjuk penyusunan dan penelaahan rencana kerja dan anggaran kementerian negara/lembaga (RKA-KL) dan pengesahan daftar isian pelaksanaan anggaran (DIPA), RKA-KL merupakan dokumen rencana keuangan tahunan $\mathrm{K} / \mathrm{L}$ yang disusun berdasarkan bagian anggaran K/L. Rencana kerja dan anggaran dalam level satuan kerja disebut dengan RKA-Satker yang berisi rencana kinerja, rincian belanja, target pendapatan, serta prakiraan maju rencana belanja dan target pendapatan satker. Penyusunan RKA-KL mengacu pada pendekatan sistem penganggaran terpadu, penganggaran berbasis kinerja (PBK), dan kerangka pengeluaran jangka menengah. PBK dapat secara jelas menunjukkan keterkaitan antara alokasi pendanaan dan kinerja yang diharapkan serta memperhatikan efisiensi dalam pencapaian kinerja (Kementerian Keuangan RI 2019). Pendekatan tersebut berbeda dengan pendekatan penganggaran tradisional atau yang biasa disebut lineitem budgeting. Pendekatan line-item budgeting disusun berdasarkan fungsi organisasi dan berorientasi pada input organisasi, umumnya dengan menambah anggaran secara bertahap. Indikator keberhasilannya diukur dari kemampuan penyerapan anggaran semata, oleh karenanya penganggaran ini dianggap kurang akuntabel (Farwitawati, Suroto, and Hadiyati 2016).

Dalam postur APBN terdapat salah satu sumber pendapatan negara yaitu penerimaan negara bukan pajak (PNBP). PNBP merupakan pendapatan negara yang bukan berasal dari pajak dan hibah. Sesuai dengan amanat dalam undangundang nomor 9 tahun 2018 tentang penerimaan negara bukan pajak. PNBP 
merupakan pungutan yang dibayar oleh orang pribadi atau badan dengan memperoleh manfaat secara langsung maupun tidak langsung atas layanan atau pemanfaatan sumber daya dan hak yang diperoleh negara, berdasarkan peraturan perundang-undangan, yang menjadi penerimaan pemerintah pusat di luar penerimaan perpajakan dan hibah dan dikelola dalam mekanisme anggaran pendapatan dan belanja negara. Adapun pihak yang melakukan penatausahaan PNBP antara lain satuan kerja atau instansi vertikal dari pemerintah pusat yang berada di daerah dengan memberikan pelayanan tertentu sesuai dengan tugas dan fungsi yang diembannya. Penyetor PNBP bukan hanya dari perorangan atau badan dari luar satuan kerja penatausaha PNBP saja, tetapi bisa juga satuan kerja dimaksud melakukan penyetoran sekaligus penatausahaan PNBP yang dilakukannya (Presiden Republik Indonesia 2018).

Menurut undang-undang nomor 9 tahun 2018 tersebut, PNBP pada prinsipnya memiliki dua fungsi, yaitu fungsi penganggaran (budgetary) dan fungsi pengaturan (regulatory). Dalam fungsi penganggaran, PNBP merupakan salah satu pilar pendapatan negara yang memiliki kontribusi cukup besar dalam menunjang APBN. Dalam fungsi pengaturan, PNBP memegang peranan penting dan strategis dalam mendukung kebijakan pemerintah untuk pengendalian dan pengelolaan kekayaan negara, termasuk pemanfaatan sumber daya alam. Meskipun dapat merencanakan pendapatan secara optimistik, beberapa negara harus menentukan projeksi penerimaan secara realistis (Potter and Diamond 1999).

\section{METODE PENELITIAN}

Melalui studi kualitatif, penelitian ini dilakukan dalam rangka melakukan peninjauan terhadap proses penganggaran PNBP di Polres Pesi. Dasar pemilihan objek penelitian adalah karena kepolisian Republik Indonesia merupakan salah satu K/L yang memiliki jenis PNBP yang banyak dan pendapatannya yang cukup besar. Metode yang digunakan adalah analisis isi (content analysis). Content analysis sebagai salah satu metode analisis teks yang cukup andal karena memandang data bukan hanya sebagai kumpulan peristiwa, namun sebagai gejala simbolik. Metode ini memiliki kelemahan karena hanya bertumpu pada data empirik dan tidak mampu menggali isi dan makna teks secara komprehensif. Content analysis bertujuan menjelaskan (to explain) variabel dari gejala yang nyata (observable) bukan memahami (to understand) fenomena sebagaimana tujuan paradigma interpretif. Content analysis juga bersifat prediktif, yakni peramalan apa yang akan terjadi di masa yang akan datang berangkat dari gejala yang dikaji untuk diperoleh generalisasi sebagai sebuah prediksi. Content analysis didasarkan atas data primer dan sekunder berikut pengolahannya selama Januari dan Februari 2020. Data primer studi ini diperoleh melalui wawancara dengan bendahara objek penelitian (lihat Tabel 1).

Tabel 1 Daftar Narasumber Kompeten

\begin{tabular}{cc}
\hline Inisial Nama & \multicolumn{1}{c}{ Jabatan } \\
\hline IM & Bendahara Penerimaan \\
AR & Bendahara Pengeluaran \\
\hline
\end{tabular}

Sumber: data olahan 
Untuk data sekunder, digunakan dokumen laporan realisasi anggaran tahun 2018 dan laporan realisasi anggaran satuan kerja untuk periode yang berakhir 31 desember 2017 dan 2018 pada Polres Pesi. Dasar pemilihan LRA sebagai data sekunder karena informasi mengenai realisasi anggaran per akun tingkat satuan kerja dapat mencerminkan kinerja anggaran K/L (aspek finansial). Di samping itu, alasan pemilihan LRA tahun 2018 adalah karena merupakan data ter-update yang diberikan oleh informan.

Selain melakukan content analysis terhadap data sekunder, dilakukan juga studi komparatif untuk menemukan akar permasalahan dalam penganggaran PNBP. Komparasi merupakan penyelidikan deskriptif yang berusaha mencari pemecahan melalui analisis tentang hubungan sebab-akibat, yakni memilih faktorfaktor tertentu yang berhubungan dengan situasi atau fenomena yang diselidiki dan membandingkannya dengan faktor lain (Surakhmad 1986, 84). Penelitian komparasi adalah sejenis penelitian deskriptif yang ingin mencari jawaban secara mendasar tentang sebab-akibat, dengan menganalisis faktor-faktor penyebab terjadinya atau munculnya suatu fenomena tertentu (Nazir 2005, 58).

Studi ini dilakukan dengan membandingkan kesesuaian penganggaran PNBP tahun 2018 dengan peraturan mengenai penyusunan anggaran yang berlaku. Hal yang dibandingkan mulai dari proses penganggaran hingga realisasinya. Data yang digunakan berupa data primer dan data sekunder. Studi diwali dengan menganalisis data dalam dokumen LRA. Karena ditemukan fakta bahwa realisasi PNBP selama dua tahun melampaui target hingga 2.000 persen, maka dilakukan perbandingan dengan aturan tentang penganggaran. Setelah diketahui fakta bahwa dalam melakukan penganggaran dapat dilakukan revisi dalam tahun berjalan, muncul dugaan sementara bahwa objek penelitian tidak mengambil opsi untuk malakukan revisi anggaran.

Untuk memperoleh data yang sebenarnya di lapangan, dilakukan komunikasi dengan pegawai KPPN sebagai instansi yang bertanggung jawab dalam mengawasi penggunaan anggaran dari objek penelitian. Pihak KPPN mengarahkan peneliti kepada bendahara penerimaan dan bendahara pengeluaran objek penelitian hingga diperoleh data primer dari wawancara. Hasil wawancara yang sebelumnya dibahas, kemudian menjadi klarifikasi atas keputusan yang diambil oleh objek penelitian. Pengolahan data dibantu Sdr. Fitri Noor Hidayah, Komang Debby Puspita Rini, dan Ni Luh Gede Desy Ardiani yang memiliki kompetensi dalam bidang pengolahan data penelitian dan penulisan.

\section{HASIL PENELITIAN DAN PEMBAHASAN}

Hampir semua organisasi swasta maupun publik dalam menjalankan operasinya berpedoman pada perspektif keuangan. Oleh sebab itu, organisasi swasta maupun publik perlu menyusun anggaran pendapatan dan belanja dalam jangka panjang yang masuk ke dalam rencana strategis serta merinci rencana strategis tersebut ke dalam anggaran pendapatan dan belanja dalam jangka pendek. Setiap organisasi atau entitas diharapkan dapat memperoleh manfaat dari proses perencanaan, penganggaran, dan pengendalian tersebut.

Kepolisian negara Republik Indonesia yang selanjutnya disebut Polri adalah salah satu lembaga pemerintah yang berperan dalam memelihara keamanan dan ketertiban masyarakat, menegakkan hukum, serta memberikan perlindungan, 
pengayoman dan pelayanan kepada masyarakat dalam rangka terpeliharanya keamanan dalam negeri. Dalam struktur keorganisasiannya di daerah, Polri memiliki Kepolisian Resor yang disebut Polres sebagai pelaksana tugas dan wewenang di wilayah kabupaten/kota. Sejalan dengan tugas dan wewenangnya, Polri dalam menjalankan tugasnya memperoleh anggaran dari APBN serta memiliki rencana pendapatan yang tercantum pula dalam APBN.

Polres memiliki beberapa fungsi yang mendasari setiap perbuatannya, meliputi fungsi pelayanan Kepolisian kepada masyarakat, misalnya penanganan laporan/pengaduan, intelijen, penyelidikan dan penyidikan tindak pidana, identifikasi, dan laboratorium forensik lapangan, pembinaan masyarakat, sabhara, dan pengaturan lalu lintas. Anggaran Polres berasal dari APBN yang dirinci ke dalam DIPA Polres masing-masing kabupaten/kota. Adapun perencanaan dan penganggarannya mengikuti ketentuan yang berlaku.

\section{Identifikasi Proses Perencanaan dan Penganggaran PNBP}

Polres Pesi melaksanakan penatausahaan PNBP sesuai dengan tugas dan fungsinya. Adapun rencana dan target PNBP ditentukan dan disampaikan setiap tahun sesuai dengan PMK Nomor 152/PMK.02/2014 tentang petunjuk penyusunan rencana penerimaan bukan pajak kementerian/lembaga. Dalam rangka mengoptimalkan PNBP guna menunjang pembangunan nasional, PNBP pada Polri sebagai salah satu sumber penerimaan negara dikelola dan dimanfaatkan untuk peningkatan pelayanan kepada masyarakat. Polri telah memiliki jenis dan tarif atas jenis PNBP sebagaimana diatur dalam peraturan pemerintah nomor 50 tahun 2010 tentang jenis dan tarif atas jenis penerimaan negara bukan pajak yang berlaku pada Polri. Jenis dan tarif PNBP ini memperjelas penatausahaan PNBP Polri (Presiden Republik Indonesia 2010). Namun, dengan adanya jenis penerimaan PNBP baru dan penyesuaian tarif, diatur kembali jenis dan tarif atas jenis PNBP yang berlaku pada Polri sesuai dengan peraturan pemerintah republik indonesia nomor pp 60 tahun 2016 tentang jenis dan tarif atas jenis penerimaan negara bukan pajak yang berlaku pada Polri. Jenis dan tarif PNBP ini memperbarui penatausahaan PNBP Polri (Presiden Republik Indonesia 2016). Pada akhir tahun 2018 tepatnya pada bulan Desember 2018, Direktur Jenderal Perbendaharaan melalui keputusan direktur jenderal perbendaharaan nomor KEP-211/PB/2018 tentang kodefikasi segmen akun pada bagan akun standar mengubah kodefikasi segmen pada bagan akun standar seluruh K/L yang sebelumya berlaku. Salah satu perubahannya adalah diubahnya kode mata anggaran penerimaan yang berawalan 423 menjadi 425. Selain itu, beberapa penerimaan diubah namanya dan dirombak kembali, serta dipindahkan menjadi penerimaan K/L lain yang telah disesuaikan dengan tugas dan fungsinya (Direktorat Jenderal Perbendaharaan 2018).

Pungutan PNBP ini dibayar oleh orang pribadi atau badan dengan memperoleh manfaat secara langsung maupun tidak langsung atas layanan atau pemanfaatan sumber daya dan hak yang diperoleh negara, berdasarkan peraturan perundang-undangan, yang menjadi penerimaan pemerintah pusat di luar penerimaan perpajakan dan hibah dan dikelola dalam mekanisme anggaran pendapatan dan belanja negara (Presiden Republik Indonesia 2018).

Pejabat instansi pemerintah wajib menyampaikan rencana PNBP tahun anggaran yang akan datang di lingkungan instansi pemerintah yang bersangkutan 
kepada Menteri Keuangan. Penyampaian rencana PNBP sebagaimana dimaksud dalam ayat dilakukan secara tertulis, wajib disampaikan paling lambat pada tanggal 15 Juli tahun anggaran berjalan. Adapun rencana PNBP perlu dilakukan revisi untuk target PNBP tahun mendatang. Pejabat instansi pemerintah wajib menyampaikan revisi Rencana PNBP dimaksud paling lambat tanggal 5 Agustus tahun anggaran yang bersangkutan kepada Menteri Keuangan. Apabila yang hendak direvisi adalah PNBP pada tahun berjalan, pejabat instansi pemerintah wajib menyampaikan revisi rencana PNBP dimaksud paling lambat tanggal 15 Agustus tahun anggaran berjalan atau sebelum penyusunan perubahan APBN tahun anggaran berjalan kepada Menteri Keuangan. Apabila tidak ada perubahan mengenai target PNBP tersebut, Menteri Keuangan dapat menetapkan rencana PNBP untuk masing-masing instansi pemerintah. Rencana PNBP ini disusun atau di-breakdown dalam bentuk target PNBP. Target PNBP disusun secara realistis dan optimal berdasarkan jenis PNBP dan tarif atas jenis PNBP, akun pendapatan sesuai Bagan Akun Standar yang terdapat di keputusan Direktur Jenderal Perbendaharaan nomor KEP-211/PB/2018 tentang kodefikasi segmen akun pada bagan akun standar, dan perkiraan jumlah/volume yang menjadi dasar perhitungan PNBP dari masing-masing jenis PNBP. Dalam penyusunan PNBP-nya, melalui PMK nomor 152/PMK.02/2014 tentang Petunjuk penyusunan rencana penerimaan negara bukan pajak kementerian/lembaga, terdapat suatu aplikasi yang disebut dengan aplikasi target penerimaan negara bukan pajak. Aplikasi target penerimaan negara bukan pajak yang selanjutnya disingkat aplikasi TPNBP, adalah aplikasi yang dikelola oleh Direktorat Jenderal Anggaran, yang digunakan untuk penyusunan rencana PNBP (Kementerian Keuangan RI 2014).

Dalam pengelolaan dan penatausahaan PNBP, terdapat suatu aplikasi yang dikelola oleh Direktorat Jenderal Anggaran juga yang disebut dengan sistem informasi penerimaan negara bukan pajak online atau yang bisa kita sebut sebagai SIMPONI. SIMPONI adalah sistem informasi yang meliputi sistem perencanaan PNBP, sistem billing, dan sistem pelaporan PNBP. Aplikasi sistem perbendaharaan dan anggaran negara, yang selanjutnya disingkat aplikasi SPAN, adalah sistem terintegrasi seluruh proses yang terkait dengan pengelolaan APBN yang meliputi modul penganggaran, modul komitmen, modul pembayaran, modul penerimaan, modul kas, dan modul akuntansi dan pelaporan.

Menurut sifatnya, terdapat dua jenis PNBP yang tersedia dalam menu aplikasi SIMPONI yaitu PNBP fungsional dan PNBP umum. PNBP fungsional merupakan PNBP yang berasal dari K/L tertentu yang tidak ada pada K/L lain, misalnya PNBP yang berasal dari Kepolisian seperti PNBP penerbitan SIM karena tidak ada tugas dan fungsi ini di K/L lainnya. PNBP umum merupakan PNBP yang berasal dari seluruh $\mathrm{K} / \mathrm{L}$, yang mana tidak dimasukkan secara khusus sebagai PNBP yang berasal dari $\mathrm{K} / \mathrm{L}$ tertentu. PNBP umum ini misalnya pendapatan dari penjualan BMN yang sudah dihapuskan dan dilelang oleh KPKNL, pendapatan sewa dari BMN idle, maupun PNBP lainnya seperti penjualan bongkaran gedung tua yang sudah tidak digunakan lagi oleh $\mathrm{K} / \mathrm{L}$ melalui mekanisme lelang di KPKNL.

Terdapat 12 jenis PNBP fungsional yang berlaku pada Polri dengan kode tiga digit pertama adalah 423 (Kepolisian Negara RI 2015). Setelah diterbitkan Keputusan Direktur Jenderal Perbendaharaan nomor KEP-211/PB/2018 tentang kodefikasi segmen akun pada bagan akun standar (BAS), bagan akun standar 
dengan kode mata anggaran penerimaan (MAP) yang dimulai dengan 3 angka depan 423 diganti seluruhnya menjadi 425 seperti terlihat pada Tabel 2.

Tabel 2 BAS dan Jenis PNBP

\begin{tabular}{cl}
\hline Kode MAP & Jenis Penerimaan Negara Bukan Pajak \\
\hline 425261 & Penerbitan Surat Izin Mengemudi (SIM) \\
425263 & Penerbitan Surat Tanda Nomor Kendaraan (STNK) \\
425264 & Penerbitan Surat Tanda Coba Kendaraan (STCK) \\
425265 & Penerbitan Buku Pemilik Kendaraan Bermotor (BPKB) \\
425266 & Penerbitan Tanda Nomor Kendaraan Bermotor (TNKB) \\
425267 & Pelayanan uji keterampilan mengemudi melalui simulator \\
425273 & Penerbitan Surat Izin Senjata Api (Senpi) dan Bahan Peledak (Handak) \\
425268 & Penerbitan Surat Mutasi Kendaraan Keluar Daerah \\
423282 & Penerbitan Surat Keterangan Catatan Kepolisian (SKCK) \\
423283 & Penerbitan Surat Keterangan Lapor Diri (SKLD) \\
423284 & Penerbitan Kartu Sidik Jari (Inafis Card) \\
423285 & Denda Pelanggaran Lalu Lintas \\
\hline
\end{tabular}

Sumber: BAS dan Jenis PNBP (KEP-211/PB/2018)

Delapan baris pertama jenis PNBP ini tetap dipungut oleh Polres, sedangkan empat sisanya sudah tidak dipungut lagi (Kepolisian Negara RI 2017). Denda pelanggaran lalu lintas dengan kode MAP 423285 berpindah menjadi PNBP yang ditarik oleh Kejaksaan Negeri dan masuk bagian anggaran Kejaksaan RI dengan kode MAP 425237.

Selain PNBP fungsional di atas, ada kalanya Polres menyetorkan PNBP umum. PNBP umum adalah PNBP yang ada di semua K/L yang sifatnya wajib disetorkan ke kas negara. Selain itu, jenis PNBP ini juga tidak selalu ada tiap bulan dan sifatnya lebih kondisional. PNBP umum antara lain pendapatan dari pemindahtanganan BMN (42512), pendapatan dari pemanfaatan BMN (42513), dan pendapatan atas pengelolaan BMN dan kekayaan negara dari pengelola barang (42514). Meskipun sifatnya yang tidak selalu ada, PNBP jenis ini tetap direncanakan jenis dan tarifnya setiap tahun. Untuk pendapatan dari pemindahtanganan BMN karena penjualan kendaraan bermotor yang dihapuskan misalnya, sudah ditetapkan berapa umur manfaat dari kendaraan dimaksud. Kemudian pada saat habis masa manfaatnya, kendaraan bermotor yang merupakan BMN ini akan dijual kepada masyarakat melalui mekanisme lelang bekerjasama dengan Kementerian Keuangan c.q. Direktorat Jenderal Kekayaan Negara c.q. Kantor Pelayanan dan Kekayaan Negara (KPKNL) terdekat. PNBP jenis ini juga disetorkan ke kas negara, tidak dikelola langsung oleh Polres sebagai satuan kerja.

Dalam laporan tahunannya, Polres Pesi telah membuat dan menyusun rencana PNBPnya seperti ini dalam kurun waktu 2 tahun yaitu 2017 dan 2018. Polres Pesi terpantau memiliki rencana anggaran pendapatan setiap tahun mulai dari tahun 2017 hingga tahun 2018 seperti terlihat pada Tabel 3.

Tabel 3 Anggaran Pendapatan Polres Pesi

\begin{tabular}{ccccc}
\hline Uraian & Tahun & & Anggaran & Kenaikan/Penurunan \\
\hline \multirow{2}{*}{ PNBP } & 2017 & $\mathrm{Rp}$ & 166.xxx.xxx & $0,00 \%$ \\
\cline { 2 - 5 } & 2018 & $\mathrm{Rp}$ & 178.xxx.xxx & $7,06 \%$ \\
\hline
\end{tabular}

Sumber: olahan dari Anggaran Pendapatan Polres Pesi 2017-2018 
Tabel 3 menunjukkan bahwa Polres Pesi telah menetapkan anggaran pendapatannya, yaitu PNBP sebesar Rp 166.xxx.xxx pada tahun 2017 dan Rp 178.xxx.xxx pada tahun 2018. Data ini diperoleh dari LRA Face Polres Pesi tahun 2017 dan tahun 2018. Setelah mengamati LRA pendapatan Polres Pesi tahun 2017 dan tahun 2018, PNBP tersebut tidak di-breakdown secara rinci dan hanya menggunakan satu kode MAP yaitu pendapatan pengamanan obyek vital dengan kode MAP 425276. Selain itu, kenaikan yang terjadi yaitu 7,06 persen mengindikasikan bahwa Polres Pesi menggunakan line item budgeting. Penganggaran ini umumnya berdasarkan atas sifat dasar dari penerimaan dan pengeluaran sesuai dengan tugas dan fungsi dari satuan kerja dengan memperhatikan histori atau kejadian-kejadian dimasa lalu dengan melakukan penyesuaian angka yang jumlahnya tidak terlalu besar atau tidak terlalu signifikan. Penyesuaian yang dilakukan memang melihat kejadian masa lalu namun tidak memperhatikan realisasi dari penerimaan itu sendiri dengan kata lain, rencana atau anggaran penerimaan tahunan didasarkan pada rencana atau anggaran penerimaan tahun sebelumnya bukan melihat realisasi dari penerimaan yang benar-benar terjadi. Tujuan utama dari metode ini adalah untuk melakukan financial control suatu organisasi atau satuan kerja pemerintah dengan berorientasi pada input atau penganggarannya saja. Selain itu dalam sektor publik, metode penganggaran yang digunakan biasanya bersifat top-down yaitu dari penganggaran APBN pada Polri dipecah ke unit-unit vertikal di daerah termasuk penganggaran PNBP-nya. Dengan kata lain, target PNBP Polres Pesi yang terdapat dalam aplikasi SIMPONI maupun SPAN merupakan hasil dari breakdown target PNBP dari pusat.

Tabel 4 Anggaran Pendapatan Polres Pesi 2017-2018

\begin{tabular}{clcccc}
\hline Kode MAP & \multicolumn{1}{c}{ Uraian } & Tahun & \multicolumn{2}{c}{ Anggaran } & $\begin{array}{c}\text { Kenaikan/ } \\
\text { Penurunan }\end{array}$ \\
\hline \multirow{2}{*}{425276} & $\begin{array}{l}\text { Pendapatan Pengamanan } \\
\text { Obyek Vital }\end{array}$ & 2017 & $\mathrm{Rp}$ & $166 . x x x . x x x$ & $0,00 \%$ \\
\cline { 2 - 5 } & 2018 & $\mathrm{Rp}$ & $178 . x x x . x x x$ & $7,06 \%$ \\
\hline
\end{tabular}

Sumber: breakdown dari penganggaran PNBP Polres Pesi 2017-2018

Berdasarkan Tabel 4, Polres Pesi hanya menggunakan satu kode mata anggaran penerimaan yaitu 425276 yang merupakan pendapatan pengamanan obyek vital. Dari tahun ke tahun, terlihat peningkatan jumlah anggaran yang nilainya tidak signifikan, yaitu dari tahun 2017 ke 2018 yang hanya naik sebesar 7,06 persen. Melihat tren kenaikan/penurunan anggaran penerimaan Polres Pesi, dapat diyakini bahwa penganggaran pendapatan atau penerimaan PNBP pada Polres Pesi menggunakan metode line item budgeting. Untuk PNBP yang sifatnya umum, Polres Pesi tidak menganggarkannya dalam dua tahun ini, terlihat dari laporan realisasi anggarannya sebagai berikut.

\section{Tabel 5 Penganggaran PNBP Umum Polres Pesi 2017-2018}

\begin{tabular}{clclc}
\hline Kode MAP & \multicolumn{1}{c}{ Uraian } & Tahun & \multicolumn{2}{c}{ Anggaran } \\
\hline \multirow{2}{*}{423141} & $\begin{array}{l}\text { Pendapatan Sewa Tanah, Gedung, dan } \\
\text { Bangunan }\end{array}$ & 2017 & $\mathrm{Rp}$ & - \\
425131 & $\begin{array}{l}\text { Pendapatan Sewa Tanah, Gedung, dan } \\
\text { Bangunan }\end{array}$ & 2018 & $\mathrm{Rp}$ & - \\
\hline
\end{tabular}

Sumber: breakdown dari penganggaran PNBP Polres Pesi 2017-2018 
Berdasarkan Tabel 5, dalam dua tahun terakhir Polres Pesi tidak menganggarkan PNBP umum sama sekali dan memasukkan anggaran PNBP dalam satu kode MAP saja yaitu 425276 yang merupakan pendapatan pengamanan obyek vital. Selain itu, tabel penganggaran PNBP umum Polres Pesi dalam LRA Tahun 2017 dan 2018 menunjukkan bahwa memang benar terjadi perubahan kode MAP dalam struktur BAS sesuai dengan Keputusan Direktur Jenderal Perbendaharaan Nomor KEP-211/PB/2018 tentang kodefikasi segmen akun pada bagan akun standar. Polres Pesi tidak menganggarkan PNBP umum secara rutin karena PNBP umum sifatnya tidak selalu ada sehingga sulit untuk ditentukan anggaran dan jumlahnya.

\section{Pengelolaan PNBP}

Dalam pelaksanaan pengelolaan PNBP dari penerimaan hingga penyetoran dana PNBP ke kas negara, satuan kerja dalam K/L yang memiliki tugas dan fungsi yang berkaitan dengan PNBP mengangkat pengelola PNBP yang terdiri dari satu bendahara penerimaan pada satuan kerja penghasil PNBP dan satu bendahara penerimaan pembantu pada setiap jenis PNBP fungsional yang dikelolanya. Untuk PNBP umum, pengelolaannya dan penatausahaannya biasanya diserahkan juga kepada bendahara penerimaan yang ditunjuk oleh satuan kerja bersangkutan. Setelah menerima pendapatan dari pihak ketiga (masyarakat) sesuai dengan jenis PNBP-nya, bendahara penerimaan sesegera mungkin menyetorkan PNBP tersebut ke kas negara melalui aplikasi SIMPONI, paling lambat satu hari setelah diterimanya PNBP tersebut. PNBP yang diterima dari masyarakat ini merupakan setoran yang dilakukan baik melalui ATM, EDC, kasir, maupun setor tunai ke bank. PNBP kemudian diproses menggunakan aplikasi SIMPONI pada laman www.simponi.kemenkeu.go.id dengan menggunakan username dan password bendahara penerimaan satker bersangkutan. Setelah berhasil masuk, bendahara penerimaan membuat billing PNBP sesuai dengan jenis PNBP tusi satkernya. Bendahara penerimaan terlebih dahulu memastikan bahwa nama kementerian dan satker sudah sesuai dengan kementerian dan satker yang menjadi perantara penerimaan PNBP.

Setelah diterbitkannya billing PNBP, bendahara penerimaan satker, dalam hal ini bendahara penerimaan Polres Pesi menyetorkan PNBP yang diterimanya ke kas negara melalui teller bank maupun melalui sistem transfer $m$-banking atau internet banking melalui rekening khusus bendahara penerimaan Polres. Aplikasi SIMPONI secara otomatis memperbarui data penyetoran PNBP yang telah dilakukan apakah sudah disetorkan ke kas negara atau masih dalam proses pengiriman. Setelah terkonfirmasi bahwa PNBP berhasil disetor ke kas negara, billing pada aplikasi SIMPONI berubah status menjadi sudah bayar dan muncul nomor tanda penerimaan negara (NTPN). Laporan konfirmasi ini secara otomatis terekap setiap bulannya dan menjadi dasar pelaporan PNBP yang dilakukan oleh bendahara penerimaan.

Aplikasi SIMPONI secara otomatis memperbarui data penyetoran PNBP yang telah dilakukan apakah sudah disetorkan ke kas negara atau masih dalam proses pengiriman. Setelah terkonfirmasi bahwa PNBP berhasil disetor ke kas negara, billing pada aplikasi SIMPONI berubah status menjadi sudah bayar dan muncul NTPN. Laporan konfirmasi ini secara otomatis terekap setiap bulannya dan menjadi dasar pelaporan PNBP yang dilakukan oleh bendahara penerimaan. 
Adapun rekap dari penyetoran PNBP dapat dimonitor melalui aplikasi SIMPONI dan SPAN. Apabila tidak terjadi kesalahan kode MAP dalam hal penyetoran PNBP maka jumlah penerimaan dari aplikasi SIMPONI dan SPAN akan sesuai jumlah dan kode MAP-nya dan tidak mempengaruhi rekonsiliasi bulanan pada aplikasi e-Rekon LK. Namun apabila dalam perjalanan ternyata ditemukan kesalahan kode MAP dan perlu dilakukan perbaikan kode MAP, maka bendahara penerimaan satuan kerja penyetor PNBP wajib melakukan koreksi atas kode MAP tersebut ke kantor pelayanan perbendaharaan negara (KPPN) setempat. Dokumen yang wajib diserahkan adalah surat pernyataan dari kantor bersangkutan bahwa telah terjadi kesalahan kode MAP pada saat melakukan penyetoran PNBP ke negara, informasi kesalahan dan koreksi atas kode MAP beserta lembar surat setoran bukan pajak dalam bentuk billing SIMPONI yang sudah berstatus "sudah bayar" dan memiliki kode NTPN. Setelah diserahkan, KPPN setempat akan sesegera mungkin melakukan koreksi kode MAP beserta jenis PNBP yang sesungguhnya. Hasil koreksi ini akan mengubah angka-angka realisasi PNBP satker pada aplikasi SPAN namun tidak mengubah angka-angka pada aplikasi SIMPONI sehingga dimungkinkan terjadi perbedaan angka. Oleh sebab itu, Bendahara Penerimaan hendaknya berhati-hati dan teliti dalam menginput data penyetoran PNBP melalui aplikasi SIMPONI sehingga tidak terjadi perbedaan dan selisih angka pada e-Rekon LK karena dapat berimbas pada rekonsiliasi bulanan satuan kerja.

\section{Realisasi Anggaran}

Sebagaimana disebutkan pada telaah literatur, hendaknya projeksi penerimaan dilakukan secara realistis. Pada tahun 2017, realisasi anggaran mencapai 2.381 persen dari yang dianggarkan. Selanjutnya pada tahun 2018 realisasi anggaran mencapai 1.998 persen dari yang ditargetkan (Tabel 6). Kenaikan anggaran dari tahun 2017 ke 2018 yaitu sebesar 7,2 persen. Dalam wawancara, bendahara objek penelitian sengaja menganggarkan PNBP fungsional hanya ke dalam satu MAP, sedangkan jenis PNBP fungsional lainnya tidak dianggarkan sama sekali. Hal tersebut dilakukan karena ketidakpastian dari jumlah PNBP yang akan diterima sehingga akan menimbulkan kemungkinan ketidaktercapaian target. Di samping itu, dari instansi vertikal di atasnya, Polda tidak menginstruksikan untuk dilakukannya revisi anggaran PNBP tersebut.

Tabel 6 Realisasi Anggaran 2017 dan 2018

\begin{tabular}{|c|c|c|c|c|c|c|}
\hline \multirow{2}{*}{ Uraian } & \multicolumn{3}{|c|}{2018} & \multicolumn{3}{|c|}{2017} \\
\hline & Anggaran & Realisasi & $\%$ & Anggaran & Realisasi & $\%$ \\
\hline $\begin{array}{l}\text { Pendapatan } \\
\text { Negara dan } \\
\text { Hibah }\end{array}$ & Rp178.xxx.xxx & Rp3.382.xxx.xxx & 1.998 & Rp166.xxx.xxx & Rp3.798.xxx.xxx & 2.381 \\
\hline
\end{tabular}

Pendapatan negara yang berasal dari PNBP fungsional dan umum pada Polres Pesi berasal dari pendapatan sewa tanah, gedung dan bangunan. Untuk PNBP yang sifatnya umum, Polres Pesi tidak menganggarkannya dalam 2 (dua) tahun ini, terlihat dari LRAnya. Walaupun tidak dianggarkan, terdapat realisasi penerimaan sekitar Rp127.000.000,00 (Tabel 7). Dari 2017 ke 2018 terdapat peningkatan sebesar 3,25 persen. 
Tabel 7 Realisasi Anggaran PNBP Umum

\begin{tabular}{lcccc}
\hline \multirow{2}{*}{ Uraian } & \multicolumn{2}{c}{$\mathbf{2 0 1 8}$} & \multicolumn{2}{c}{2017} \\
\cline { 2 - 5 } & Estimasi & Realisasi & Estimasi & Realisasi \\
\hline $\begin{array}{l}\text { Pendapatan Sewa Tanah, } \\
\text { Gedung dan Bangunan }\end{array}$ & - & Rp127.xxx.xxx & - & \multirow{2}{*}{ Rp123.xxx.xxx } \\
\hline Sumber: olahan dari realisasi anggaran PNBP umum & &
\end{tabular}

Dari enam belas PNBP fungsional yang dapat ditarik Kepolisian, Polres Pesi memiliki PNBP fungsional terdiri dari pendapatan pengamanan obyek vital, penerbitan surat izin mengemudi (SIM), pendapatan perpanjangan surat izin mengemudi (SIM); pendapatan penerbitan surat tanda nomor kendaraan bermotor (STNK); pendapatan pengesahan surat tanda nomor kendaraan bermotor (STNK); pendapatan tanda nomor kendaraan bermotor (TNKB); pendapatan penerbitan surat mutasi kendaraan ke luar daerah; dan pendapatan penerbitan surat izin senjata api dan bahan peledak dan penerbitan surat keterangan catatan kepolisian. PNBP fungsional diestimasikan sejumlah seratus tujuh puluh delapan juta rupiah. Estimasi pendapatan ini berasal dari pendapatan pengamanan obyek vital. Pada LRA, estimasi PNBP fungsional selain pendapatan pengamanan obyek nilainya nol.

Pada Tabel 8 anggaran 2018 diketahui untuk pendapatan pengamanan obyek atau targetnya sebesar Rp 178 juta. Jumlah yang terealisasi sebesar 94,94 persen dari target. Pendapatan pengamanan obyek menyumbang 5 persen dari total realisasi pendapatan. Anggaran 2017 menunjukkan, pendapatan untuk pengamanan obyek diestimasikan sebesar Rp160 juta. Pendapatan ini terealisasi sebesar 68,07 persen dari target. Pendapatan untuk pengamanan obyek menyumbang 2,98 persen dari total realisasi. Dari total pendapatan, hanya pendapatan pengamanan obyek yang dapat dianggarkan.

Tabel 8 Realisasi Pendapatan Pengamanan Obyek

\begin{tabular}{lcccc}
\hline \multirow{2}{*}{ Uraian } & \multicolumn{2}{c}{$\mathbf{2 0 1 8}$} & \multicolumn{2}{c}{2017} \\
\cline { 2 - 5 } $\begin{array}{l}\text { Pendapatan } \\
\text { Pengamanan Obyek }\end{array}$ & Rp178.xxx.xxx & Rp169.xxx.xxx & Rp166.xxx.xxx & Rp113.xxx.xxx \\
\hline Sumber: olahan dari realisasi anggaran PNBP umum & & Realisasi \\
\hline
\end{tabular}

Berdasarkan Tabel 9, penerbitan dan perpanjangan surat izin mengemudi (SIM) berkontribusi sebesar 31,79 persen dari total realisasi pendapatan. Pendapatan penerbitan surat izin mengemudi (SIM) menyumbang 25,61 persen dari total pendapatan. Perpanjangan surat izin mengemudi menyumbang 6,18 persen dari total pendapatan. Dibandingkan tahun 2017, pendapatan penerbitan dan perpanjangan sim meningkat sebesar 17,1 persen.

Tabel 9 Realisasi PNBP Penerbitan dan Perpanjangan SIM

\begin{tabular}{lcccc}
\hline \multirow{2}{*}{ Uraian } & \multicolumn{2}{c}{$\mathbf{2 0 1 8}$} & $\mathbf{2 0 1 7}$ \\
\cline { 2 - 5 } & Estimasi & Realisasi & Estimasi & Realisasi \\
\hline Penerbitan SIM & - & Rp 866.xxx.xxx & - & Rp 697.xxx.xxx \\
Pendapatan Perpanjangan SIM & - & Rp 209.xxx.xxx & - & Rp 221.xxx.xxx \\
\hline
\end{tabular}

Sumber: olahan dari realisasi anggaran PNBP umum

Berdasarkan Tabel 10, pendapatan penerbitan surat tanda nomor kendaraan bermotor (STNK) berkontribusi sebesar 29,86 persen dari total 
pendapatan. Dibanding tahun 2017, pendapatan tahun 2018 mengalami penurunan sebesar 50,44 persen. Namun, dari tahun 2017 tidak dianggarkan berapa pendapatan akan diterima. Padahal jumlahnya sangat signifikan dan paling besar di antara yang lain.

Tabel 10 Penerbitan Surat Tanda Nomor Kendaraan Bermotor (STNK)

\begin{tabular}{ccccc}
\hline & \multicolumn{2}{c}{$\mathbf{2 0 1 8}$} & \multicolumn{2}{c}{2017} \\
\cline { 2 - 5 } Uraian & Estimasi & Realisasi & Estimasi & Realisasi \\
\hline Pendapatan Penerbitan STNK & - & Rp1.010.xxx.xxx & - & Rp2.038.xxx.xxx \\
\hline Sumber:
\end{tabular}

Sumber: olahan dari realisasi anggaran PNBP umum

Berdasarkan Tabel 11, pengesahan surat tanda nomor kendaraan bermotor (STNK) dan pendapatan tanda nomor kendaraan bermotor (TNKB) menyumbang sebesar 21,68 persen dari total pendapatan. Pada tahun 2017 PNBP jenis pendapatan pengesahan surat tanda nomor kendaraan bermotor (STNK) belum ada. Pada tahun 2017, pendapatan tanda nomor kendaraan bermotor berkontribusi sebesar 7,87 persen dari total pendapatan 2017. Jumlah ini meningkat pada tahun 2018 sebesar 74,25 persen dari tahun 2017.

Tabel 11 Realisasi Pendapatan Pengesahan STNK dan Pendapatan TNKB

\begin{tabular}{lcccc}
\hline & \multicolumn{2}{c}{$\mathbf{2 0 1 8}$} & \multicolumn{2}{c}{2017} \\
\cline { 2 - 5 } \multicolumn{1}{c}{ Uraian } & Estimasi & Realisasi & Estimasi & Realisasi \\
\hline Pendapatan Pengesahan STNK & - & Rp 211.xxx.xxx & - & - \\
Pendapatan TNKB & - & Rp 521.xxx.xxx & - & Rp 299.xxx.xxx \\
\hline Sumb:
\end{tabular}

Sumber: olahan dari realisasi anggaran PNBP umum

Berdasarkan Tabel 12, pendapatan penerbitan surat mutasi kendaraan ke luar daerah mengalami penurunan dibanding 2017. Penurunan terjadi sebesar 39,29 persen atau sekitar dua puluh dua juta rupiah. Dibanding pendapatan lainnya, PNBP jenis ini berkontribusi paling sedikit pada total pendapatan, yaitu sebesar 1 persen.

Tabel 12 Realisasi Pendapatan Penerbitan Surat Mutasi Kendaraan ke Luar Daerah

\begin{tabular}{lcccc}
\hline \multirow{2}{*}{ Uraian } & & \multicolumn{2}{c}{$\mathbf{2 0 1 8}$} & \multicolumn{2}{c}{$\mathbf{2 0 1 7}$} \\
\cline { 2 - 5 } $\begin{array}{l}\text { Pendapatan } \\
\text { Mutasi Kendaraan Ke Luar Daerah }\end{array}$ & - & Rp34.xxx.xxx & - & \multirow{2}{*}{ Rp56.xxx.xxx } \\
\hline
\end{tabular}

Sumber: olahan dari realisasi anggaran PNBP umum

Bardasarkan Tabel 13, dapat dibandingkan dengan tahun 2018, di tahun 2017 terdapat pendapatan berupa pendapatan surat catatan kepolisian dan penerimaan kembali belanja barang tahun anggaran yang lalu. Pada tahun 2017 tidak ada pendapatan penerbitan surat izin senjata api dan bahan peledak (SISABP) dan penerbitan surat keterangan catatan kepolisian (SKCK). 
Tabel 13 Realisasi Pendapatan Penerbitan (SISABP) dan (SKCK)

\begin{tabular}{lcccc}
\hline \multirow{2}{*}{ Uraian } & \multicolumn{2}{c}{2018} & \multicolumn{2}{c}{2017} \\
\cline { 2 - 5 } & Estimasi & Realisasi & Estimasi & Realisasi \\
\hline $\begin{array}{l}\text { Pendapatan Penerbitan SISABP } \\
\text { dan SKCK }\end{array}$ & - & Rp408.xxx.xxx & - & - \\
\hline Pendapatan Penerbitan SKCK & - & - & - & Rp370.xxx.xxx \\
\hline
\end{tabular}

Sumber: olahan dari realisasi anggaran PNBP umum

Perbedaan akun-akun ini disebabkan karena terdapat perubahan kodefikasi segmen akun berdasarkan penerbitan Keputusan Direktorat Jenderal Perbendaharaan nomor KEP-658/PB/2017 tentang perubahan atas KEP617/PB/2017 tentang pemutakhiran kodefikasi segmen akun pada bagan akun standar. Keputusan baru menetapkan akun pendapatan penerbitan surat catatan kepolisian digabung dengan pendapatan penerbitan surat izin senjata api dan bahan peledak menjadi satu akun dengan nama pendapatan penerbitan surat izin senjata api dan bahan peledak dan penerbitan surat keterangan catatan kepolisian (Direktorat Jenderal Perbendaharaan 2017).

Pembuatan anggaran di Indonesia menggunakan akun-akun sebagai standar dengan tujuan menyeragamkan format anggaran seluruh kuasa pengguna anggaran. Keseragaman format anggaran, akan memudahkan top level management membandingkan anggaran dan mengukur kinerja suatu unit bisnis dengan unit bisnis lainnya. Selain itu dapat menjadi bahan evaluasi dan menjadi pelajaran bagi satuan kerja lain agar bisa mencontoh satuan kerja dengan penganggaran dan realisasi terbaik.

Sesuai dengan tugas dan fungsi kepolisian, maka setiap satuan kerja akan memiliki akun-akun pendapatan yang sama. Akun-akun PNBP, yang terealisasi tidak semua diestimasi dalam budget sebelumnya. Dari semua akun-akun itu, hanya pendapatan untuk pengamanan obyek yang dapat diestimasi untuk budgeting. Melihat sifat alami bisnis satuan kerja kepolisian, jenis usaha yang dilakukan seperti perusahaan jasa. Dalam hal ini, jasa yang diberikan kepada pelanggannya (masyarakat) adalah pengamanan, penerbitan surat tanda nomor kendaraan bermotor, penerbitan tanda nomor kendaraan bermotor, penerbitan surat izin mengemudi, penerbitan surat izin senjata api dan bahan peledak, penerbitan surat keterangan catatan kepolisian, dan surat mutasi kendaraan ke luar daerah.

Pendapatan yang berkaitan dengan administrasi atau penerbitan surat-surat saat ini belum dapat diperhitungkan estimasinya. Hal ini dikarenakan faktor eksternal atau faktor yang di luar kendali satuan kerja dan faktor internal. Penerbitan surat tanda kendaraan bermotor dan tanda nomor kendaraan bermotor belum dapat diestimasi karena belum tersedianya data terkait estimasi jumlah penjualan kendaraan bermotor yang akan datang di daerah itu (faktor eksternal) dan data motor lama yang di tahun itu akan melakukan perpanjangan surat atau tanda nomor kendaraan (faktor internal). Sama halnya dengan pendapatan penerbitan surat tanda kendaraan bermotor, penerbitan surat izin mengemudi dan perpanjangannya, serta penerbitan surat izin senjata api dan bahan peledak membutuhkan data estimasi pembelian serta data kepemilikan surat izin tersebut untuk perpanjangannya. Data yang merupakan faktor eksternal inilah yang membuat pendapat pendapatan-pendapatan tersebut sulit diestimasi. 
Pendapatan penerbitan surat keterangan catatan kepolisian bergantung pada kebutuhan masyarakat terkait surat ini (faktor eksternal). Surat ini hanya akan diterbitkan jika ada permohonan dari masyarakat. Surat ini biasanya dibutuhkan oleh masyarakat sebagai persyaratan untuk melamar pekerjaan dan mendaftar sekolah kedinasan. Kebutuhan masyarakat terhadap surat keterangan ini belum dapat diprediksi. Menurut peneliti, untuk estimasi anggarannya, satuan kerja kepolisian dapat menggunakan pendekatan statistika yaitu rata-rata dan/atau nilai terbawah dari realisasi selama lima tahun ke belakang sebagai dasar perhitungan anggaran pendapatan ini.

Walaupun sulit diestimasi, anggaran dapat diperbaiki saat tahun berjalan. Peraturan mengenai anggaran, PMK 152/PMK.02/2014, mengizinkan satuan kerja untuk membuat perubahan pada pertengahan tahun berjalan. Pasal 18 peraturan yang sama menyebutkan, jika kementerian lembaga tidak menyampaikan perubahan rencana PNBP, Kementerian Keuangan c.q. Direktorat Jenderal Anggaran dapat melakukan perhitungan perubahan rencana PNBP K/L berdasarkan capaian PNBP (Kementerian Keuangan RI 2014). PNBP yang dihasilkan disetor oleh penerima layanan maksimal pada hari diterimanya layanan. Capaian PNBP pada saat waktu revisi seharusnya sudah ada tetapi tidak dilakukan perubahan berdasarkan capaian PNBP. Realisasi pendapatan tersebut dapat ditingkatkan melalui perbaikan proses (misalnya mempersingkat waktu tunggu atau mempermudah alur pembuatan permohonan izin) dan teknologi (menyediakan database seperti data kendaraan yang telah diterbitkan surat tanda nomor kendaraan dan tanda nomor kendaraan bermotornya, data pemilik surat izin mengemudi) sehingga dapat menarik masyarakat.

\section{Implikasi Realisasi Anggaran yang Melampaui Target}

Berdasar uraian sebelumnya, realisasi PNBP melebihi anggaran. Hansen and Mowen (2007) menyebutkan bahwa sistem anggaran yang ideal, merupakan budget yang menyediakan feedback pada performance-nya sehingga manajemen dapat mengukur kinerjanya. Selain itu sistem budget yang ideal memiliki insentif dalam satuan uang atau bukan satuan uang, dalam pembuatannya melibatkan seluruh level manajer, memiliki standar yang realistis, menampilkan controllable cost (atau jenis biaya yang dapa dikendalikan) dan menyediakan beberapa metode pengukuran kinerja. Untuk melibatkan manajer dari berbagai level, target anggaran penjualan dapat ditentukan menggunakan bottom-up. Keunggulan jika penganggaran dilakukan bottom-up adalah anggaran lebih realistis, partisipatif, dan karyawan lebih puas (Ginting 2018). Studi Pundarika and Dwirandra (2018) menegaskan bahwa keterlibatan pegawai dalam penganggaran dapat mengurangi sistem penganggaran yang tidak baik (budgetary slack). Pada anggaran satuan kerja ini anggaran yang ditetapkan bisa dikatakan bersifat "too pessimistic" karena sudah dua tahun anggaran, realisasinya jauh di atas anggarannya. Namun targetnya tetap dibuat di bawah realisasi tahun sebelumnya. Hal ini disebabkan pihak-pihak terkait penganggaran belum dapat mengestimasi untuk pendapatan seperti yang contoh pada bagian realisasi sebelumnya.

Saat ini belum ada peraturan mengenai standar yang realistis dari PNBP yang harus dihasilkan satuan kerja kepolisian setiap tahunnya. Ada beberapa cara dapat digunakan untuk memperoleh standar yang realistis. Salah satunya dengan cara benchmarking. Misalnya, menetapkan standar dari realisasi salah satu satuan 
kerja kepolisian yang terendah pada tahun sebelumnya, atau perhitungan rata-rata realisasi PNBP seluruh satuan kerja di Indonesia. Cara lain yaitu menggunakan realisasi anggaran pada tahun sebelumnya dapat menjadi standar untuk dilampaui.

Menurut performance budgeting, kinerja tahun sebelumnya dapat menjadi dasar atau pertimbangan penentuan target kinerja tahun berikutnya. Dengan kata lain, penganggaran mendasarkan atas capaian kinerja sebelumnya yang telah dicapai (Puspitasari 2013). Jika tahun 2017 realisasi mencapai 2.381 persen target, maka pada tahun 2018 target atau anggaran pendapatannya seharusnya menyesuaikan realisasi 2017. Karena kinerja 2017 sudah baik, maka seharusnya target pada tahun selanjutnya disesuaikan dengan tahun sebelumnya. Pendapatan yang jauh melebihi targetnya bukan berarti sesuatu yang baik, bisa dikarenakan estimasi anggarannya yang kurang baik.

Berdasarkan Peraturan Menteri Keuangan Nomor 152/PMK.02/2014, Pasal 5 menyebutkan rencana PNBP dalam rangka penyusunan Pagu Indikatif disusun dengan berpedoman pada rencana PNBP tahun anggaran berjalan, realisasi PNBP tahun anggaran sebelumnya, dan kebijakan pemerintah. Maka, kinerja target tahun sebelumnya menjadi pertimbangan dalam menentukan target pada tahun yang direncanakan.

Realisasi anggaran pendapatan yang jauh melampaui target ini disebabkan karena estimasi pendapatan yang belum baik. Implikasinya adalah anggaran tidak dapat digunakan untuk mengukur kinerja dan tidak dapat digunakan untuk pengawasan (control). Untuk meningkatkan hasil, penganggaran juga perlu disusun bersama, tidak hanya digawangi oleh bendahara penerimaan, tetapi unsur pimpinan kepolisian. Disadari memang tugas dan fungsi kepolisian memang terkait pengamanan dan ketertiban masyarakat, namun pengelolaan PNBP juga dapat ditingkatkan melalui perencanaan dan pengendalian yang baik. Sebagian PNBP yang dihasilkan dapat diminta dan digunakan untuk memperbaiki proses dan teknologi layanan. Hal ini selaras dengan studi Isaac, Lawal, \& Okoli (2015) bahwa, "It therefore recommended that since budgeting and budgetary control contributes to management efficiency and high productivity of an organization, all relevant stakeholders must be involved in the budget process, from preparation to implementation, in other to guarantee overall goal attainment." Artinya, untuk mendorong efisiensi dan efektivitas penganggaran, kepolisian dan pihak terlibat penting melakukan perbaikan, termasuk KPPN dan Kanwil DJA di daerah. Sinergi untuk penganggaran yang baik akan meningkatkan pengelolaan APBN secara lebih akuntabel. Hal ini diperkuat studi Anggriyani and Rambe (2016) bahwa hubungan partisipasi dalam penganggaran meningkatkan kinerja manajerial.

Implikasi lain dari tidak diestimasikannya anggaran pendapatan adalah satuan kerja Polres Pesi tidak dapat menggunakan sebagian realisasi dana PNBP untuk membiayai kegiatan operasionalnya. Salah satu insentif dari sistem penganggaran PNBP adalah sebagian dana PNBP yang dapat digunakan oleh satker yang menghasilkan. Berdasarkan peraturan Kapolri Nomor 1 Tahun 2015, pasal 14, sebagian dana PNBP dapat digunakan untuk membiayai kegiatan yang meliputi: (1) pelayanan di bidang penerbitan SIM, STNK, STCK, BPKB, TNKB, ujian keterampilan mengemudi, melalui simulator/surat keterangan uji keterampilan pengemudi (SKUKP), surat mutasi kendaraan keluar daerah, kartu sidik jari, izin penggunaan senjata api, bahan peledak, SKCK dan SKLD; (2) 
penindakan pelanggaran lalu lintas jalan; (3) koordinasi antar instansi terkait; (4) operasional, pemeliharaan, dan investasi termasuk peningkatan kualitas sumber daya manusia di bidang lalu lintas; dan (5) operasional, pemeliharaan, dan investasi termasuk peningkatan kualitas sumber daya manusia pada fungsi intelijen dan keamanan, fungsi Reskrim bidang identifikasi.

Pencairan dana PNBP pada satker Polri yang di kewilayahan/daerah dilakukan sebesar 1/12 (satu per dua belas) setiap bulan dari pagu DIPA PNBP. Sesuai peraturan, maka satker tidak dapat menggunakan PNBP secara optimal sesuai potensi PNBP. Padahal mengacu pada PMK nomor 237/KMK.02/2010, setelah PNBP disetorkan ke kas negara maka bendahara pengeluaran dapat mencairkan sebagian dana PNBP untuk kegiatan pelayanan maksimal 85,54 persen dari total nilai PNBP yang diterima (Nursanti, Mas'ud, and Alam, 2019). Studi Suryawati, Hikmayani, dan Purnomo (2010) juga menekankan implikasi perlunya pengalokasian dana PNBP untuk peningkatan layanan.

\section{KESIMPULAN}

Secara umum Polres Pesi sudah melaksanakan penganggaran PNBP fungsional sesuai dengan ketentuan yang berlaku, meskipun penganggarannya tidak dirinci ke berbagai kode mata anggaran penerimaan. Polres hanya menggunakan satu kode mata anggaran penerimaan 425276 yang merupakan pendapatan yang diperoleh dari kegiatan pengamanan obyek vital. PNBP umum tidak dianggarkan oleh Polres Pesi karena sifatnya yang tidak selalu ada dan rutin sehingga sulit untuk diukur jumlahnya. Penganggaran PNBP yang dilakukan bersifat line-item budgeting dengan metode top-down yaitu target angka penerimaan PNBP ditetapkan pusat, kemudian diserahkan kepada satuan kerja terkait. Sebaiknya, Polres Pesi merinci target penerimaan PNBP sesuai dengan kode MAP yang tercantum pada Keputusan Direktur Jenderal Perbendaharaan Nomor KEP-211/PB/2018 tentang kodefikasi segmen akun pada bagan akun standar dengan memperhatikan realisasi yang sudah dilaksanakan pada tahun sebelumnya.

Implikasi penerapan line-item budgeting adalah anggaran menjadi terlalu global (tidak rinci) dan pengukuran kinerja tiap item kurang terlihat jelas. Pendapatan yang belum diestimasi sebelumnya akan muncul pada LRA dengan nilai nol. Beberapa faktor eksternal menjadi penyebab estimasi pendapatan pada satuan kerja Kepolisian sulit untuk diestimasikan. Akibat realisasi anggaran yang ditargetkan jauh dari target awal menyebabkan anggaran pendapatan tidak dapat digunakan sebagai alat untuk mengukur kinerja dan alat untuk mengawasi kinerja tahun anggaran berjalan. Namun demikian, mengingat studi ini dibatasi waktu, tren perbaikan pola penganggaran, misalnya penganggaran berbasis kinerja, belum terlihat. Hal ini karena Polres termasuk institusi pusat yang dalam penganggaran tetap mengacu pada undang-undang keuangan negara. Studi ini juga menjadikan Polres Pesi sebagai satu objek penelitian, belum dibandingkan dengan satuan kerja lainnya yang memiliki tugas fungsi pelayanan kepada masyarakat dan menerapkan penerimaan PNBP.

Saran penelitian berikutnya adalah memperlebar rentang waktu penelitian hingga data terkini sehingga apakah pola penganggaran line-item budgeting secara konsisten diterapkan atau ada bauran dengan penganggaran berbasis kinerja 
sebagaimana diinginkan undang-undang keuangan negara. Di samping itu, studi berikutnya dapat membuat analisis perbandingan penatausahaan PNBP Polres Pesi dengan satuan kerja lainnya yang memiliki tugas dan fungsi pelayanan kepada masyarakat dan menerapkan penerimaan PNBP. Pada bagian akhir, studi juga perlu membandingkan satuan kerja dengan pola penganggaran lama line-item budgeting dengan pola penganggaran baru berbasis kinerja, atau bauran keduanya.

\section{DAFTAR PUSTAKA}

Anggriyani, Anggriyani, and Syahrul Rambe. 2016. "Partisipasi Karyawan Berpengaruh Terhadap Performance Manajerial Dalam Penyusunan Anggaran Dengan Komitmen Organisasi Dan Reward Sebagai Variabel Moderating". Jurnal Akuntansi, Keuangan \& Perpajakan Indonesia (JAKPI) 3 (1), 15-40. https://jurnal.unimed.ac.id/2012/index.php/eua/article/view/7426.

Direktorat Jenderal Perbendaharaan. 2017. Keputusan Direktorat Jenderal Perbendaharaan Nomor KEP-658/PB/2017 Tentang Perubahan Atas KEP-617/PB/2017 Tentang Pemutakhiran Kodefikasi Segmen Akun Pada Bagan Akun Standar. Jakarta: Direktorat Jenderal Perbendaharaan Kementerian Keuangan Republik Indonesia.

Direktorat Jenderal Perbendaharaan. 2018. Keputusan Direktur Jenderal Perbendaharaan Nomor KEP-211/PB/2018 Tentang Kodefikasi Segmen Akun Pada Bagan Akun Standar. Jakarta: Direktorat Jenderal Perbendaharaan Kementerian Keuangan Republik Indonesia.

Farwitawati, Reni, Bambang Suroto, dan Hadiyati Hadiyati. 2016. "Analisis Implementasi Anggaran Berbasis Kinerja Pada Pemerintahan Kabupaten Siak Provinsi Riau". Jurnal Ilmiah Ekonomi dan Bisnis 13 (2), 208-228. https://journal.unilak.ac.id/index.php/JIEB/article/view/853.

Ginting, Mitha Christina. 2018. "Partisipasi Anggaran Dan Kinerja Manajerial Organisasi”. Jurnal Manajemen 4 (1), 23-33. http://ejournal.lmiimedan.net/index.php/jm/article/view/27.

Hansen, Don R., and Maryanne M. Mowen. 2007. Management Accounting, 8e. USA: Thompson South-Western.

Isaac, Lambe, Mary Lawal, Theresa Okoli. 2015. "A Systematic Review of Budgeting and Budgetary Control in Government Owned Organizations". Research Journal of Finance and Accounting 6 (6), 1-10. https://iiste.org/Journals/index.php/RJFA/article/view/21157.

Kementerian Keuangan RI. 2014. Peraturan Menteri Keuangan Nomor 152/PMK.02/2014 Tentang Petunjuk Penyusunan Rencana Penerimaan Bukan Pajak Kementerian Negara/Lembaga. Jakarta: Kementerian Keuangan Republik Indonesia.

Kementerian Keuangan RI. 2019. Peraturan Menteri Keuangan Nomor 208/PMK.02/2019 Tentang Petunjuk Penyusunan Dan Penelaahan Rencana Kerja Dan Anggaran Kementerian Negara/Lembaga Dan Pengesahan Daftar Isian DIPA. Jakarta: Kementerian Keuangan Republik Indonesia. 
Kepolisian Negara RI. 2015. Peraturan Kepala Kepolisian Negara Republik Indonesia Nomor 1 Tahun 2015 Tentang Pengelolaan Penerimaan Negara Bukan Pajak Pada Kepolisan Negara Republik Indonesia. Jakarta: Kepolisan Negara Republik Indonesia.

Kepolisian Negara RI. 2017. Peraturan Kepala Kepolisian Negara Republik Indonesia Nomor 3 Tahun 2017 Tentang Perubahan Atas Peraturan Kepala Kepolisian Negara Republik Indonesia Nomor 1 Tahun 2015 Tentang Pengelolaan Penerimaan Negara Bukan Pajak Pada Kepolisan Negara Republik Indonesia. Jakarta: Kepolisan Negara Republik Indonesia.

Mihaela, Cretu Carmen, Gheonea Victoria, Talaghir Laurentiu Gabriel, Manolache Gabriel Marian, and Iconomescu Teodora Mihaela. 2010. "Budget - Performance Tool In Public Sector". Proceedings of the 5th WSEAS International Conference On Economy And Management Transformation 1, 360-368. http://dx.doi.org/10.13140/2.1.1033.9849.

Nafarin, M. 2000. Penganggaran Perusahaan. Jakarta: Salemba Empat.

Nazir, Moh. 2005. Metode Penelitian. Jakarta: Ghalia Indonesia.

Nursanti, Nursanti, Masdar Mas'ud, and Nur Alam. 2019. "Efektivitas Dan Pengelolaan Penerimaan Negara Bukan Pajak". PARADOKS: Jurnal Ilmu Ekonomi 2 (4), 97-109. http://jurnal.fe.umi.ac.id/index.php/PARADOKS/article/view/299.

Nwokeji, Nkechi Emeka. 2009. "Budget and Budgetary Control: Key to Planning and Control in Public Sector". Available at SSRN: https://ssrn.com/abstract=3367201.

Potter, Barry H., and Jack Diamond. 1999. Guidelines For Public Expenditure Management. Washington DC.: International Monetary Fund.

Presiden Republik Indonesia. 1997. Undang-Undang Nomor 20 Tahun 1997 Tentang Penerimaan Negara Bukan Pajak. Jakarta: Presiden Republik Indonesia.

Presiden Republik Indonesia. 2010. Peraturan Pemerintah Nomor 50 Tahun 2010 Tentang Jenis Dan Tarif Atas Jenis Penerimaan Negara Bukan Pajak Yang Berlaku Pada Kepolisian Negara Republik Indonesia. Jakarta: Presiden Republik Indonesia.

Presiden Republik Indonesia. 2016. Peraturan Pemerintah Republik Indonesia Nomor PP 60 Tahun 2016 Tentang Jenis Dan Tarif Atas Jenis Penerimaan Negara Bukan Pajak Yang Berlaku Pada Kepolisian Negara Republik Indonesia. Jakarta: Presiden Republik Indonesia.

Presiden Republik Indonesia. 2018. Undang-Undang Nomor 9 Tahun 2018 Tentang Penerimaan Negara Bukan Pajak. Jakarta: Presiden Republik Indonesia.

Pundarika, I Gede Putu \& A.A.N.B Dwirandra. 2018. “The Effect Of Budget Participation On Budgetary Slack With Organizational Commitments And Love Of Money As Moderation". International Journal of Science and $\begin{array}{lllll}\text { Research } & \text { (IJSR) } & 8 & \text { (2), }\end{array}$ https://www.ijsr.net/get_abstract.php?paper_id=ART20195068.

Puspitasari, Ratna. 2013. "Studi Penganggaran Berbasis Kinerja Pada Pemerintah Provinsi Jawa Timur, Jawa Barat, dan DKI Jakarta”. Jejaring Administrasi 
Publik 5 (2), 356-369. http://journal.unair.ac.id/download-fullpapersadmpc61c8ea382full.pdf

Supriyono. 1990. Manajemen Strategi \& Kebijaksanaan Bisnis. Yogyakarta: BPFE Universitas Gajah Mada.

Surakhmad, Winarno. 1986. Pengantar Interaksi Mengajar Belajar Dasar dan Teknik Metodologi Pengajaran. Bandung: Tarsito.

Suryawati, Siti Hajar, Yayan Hikmayani, and Agus Heri Purnomo. 2010. "Strategi

Peningkatan Dan Alokasi Penerimaan Negara Bukan Pajak Untuk Peningkatan Operasional Layanan Pelabuhan Perikanan”. Jurnal Sosial Ekonomi Kelautan dan Perikanan 5 (2), 211-225. http://dx.doi.org/10.15578/jsekp.v5i2.5802. 